\title{
Total Quality Management Role in Organizational Change and Development - Case Study: Taif University
}

\author{
Atallah Basheer Alnaweigah ${ }^{1}$ \\ ${ }^{1}$ Financial and Administrative Sciences College, Taif University, Taif, Saudi Arabia \\ Correspondence: Dr. Atallah Basheer Alnaweigah, Assistant Professor, Financial and Administrative Sciences \\ College, Taif University, Taif, Saudi Arabia. Tel: 966-59-170-0058. E-mail: atasami@yahoo.com
}

Received: May 28, 2013

Accepted: June 24, 2013

Online Published: July 2, 2013

doi:10.5430/ijba.v4n4p55

URL: http://dx.doi.org/10.5430/ijba.v4n4p55

\begin{abstract}
The study aimed to examine the TQM role in the organizational change and development of Taif University; to answer the following questions: What is TQM role in organizational change and development of Taif University? Are there any statistical significant differences due to the age, gender, degree, level of scientific experience, nature of work and programs? Therefore a questionnaire was designed and launched to collect the required data, once data was obtained, the statistical analysis process using SPSS program started to reach to the paper findings (The study population consisted of all full-time academics at Taif University (328). A random sample was selected of (159).

The study showed the following results: the TQM role in organizational change and development of Taif University was highly significant due to the positive correlation between the TQM practicing organizational change and development, there were no statistical significant differences for age, gender, degree, level of scientific experience, nature of work and programs. Based on the study results, the researcher recommended to emphasis on increasing awareness in practicing TQM due to the significant impact on improving performance.
\end{abstract}

Keywords: total quality, organizational change, development

\section{Introduction}

The reform of education has received considerable attention in most countries of the world, the significant quality of this attention was proved, to the extent that intellectuals called this era "the era of quality", as one of cornerstones of new management model that has been created to cope with international and local variables trying to adapt the global community to consider the quality and educational reform as two sides of one coin, so it can be said that the overall quality is the real challenge that will face world in the coming decades.

The need to apply quality management systems in universities proved effectiveness in many developed countries. Universities considered such systems as a prerequisite for outstanding performance as means needed to avoid errors, problems, and obstacles that may impede the educational process.

As a result of the successes, quality applications were adopted received in developed countries and developing countries including Arab countries. TQM is an approach commonly used in private business to focus on improving service standards to the customers. TQM strives to continuously improve customer satisfaction by improving the service delivery process (Taylor-Powell 1990).

Modern organizations seeking to achieve quality of their services and operations, setting them as a key in a rapidly changing world of intense competition in the provision of goods and services. In light of tough global competition for different types of organizations to gain higher market share. It is the client (beneficiary) the master of the situation who seek to satisfy the requirements of the allure for increased market share for these organizations, which have become dependent upon their survival and continuity. Recently, higher education has witnessed great interest at all levels, for the application of standards and procedures. Managing the overall quality, access to the development and ongoing change improvement, to keep pace with the progress of society considering the individual needs of the social, economic, political and cultural rights.

Taif University is one of higher education institutions started to apply TQM. Taif University was established in the Kingdom of Saudi Arabia in 2003. The University adopted the TQM management techniques in 2007. 


\section{Problem and Questions of the Study}

In this study was to explore and monitor the role of TQM in Practicing Organizational Change and Development in Taif University, has been dealing with the problem of the study, with the main the following question: First main of the question: What is the role of TQM in Practicing Organizational Change and Development in Taif University (elements of the seven adopted in this study)? It is divided on the question of main the following sub-questions

1). What is the role of TQM in practicing organizational change and development in Taif University from where Focus on students, Organizational culture, The design of operations, Support senior management of quality, Continuous improvement, Focus on academics, Quality assurance?

2). Are there any statistical significant differences at the level $(\alpha \geq 0,05)$ due to the Age, gender, Degree, Level of scientific, experience, nature of work and Programs?

\section{The Importance of the Study}

The importance of this study stems from the importance of the subject matter, which is managed by Taif University, staff and students and the surrounding community through the study of trends towards the application of full-time academics TQM at Taif University, and the implications of this level of application-level change and organizational development at the university. The choice of the university to the method of TQM is no longer subject to frequency, and distance from the entrance leads to the degradation and decline in performance and then to retreat from its shareholder making the future of their societies. As well as the importance of this study stems from interest in studying the relationship between the application of TQM, and the impact on development and organizational change, which is the result of the application of TQM University, which is in constant improvement and development of the path of the University technical, administrative and consistent with the scientific and technological developments in the world of rapid development and progress.

\section{Study Objectives}

This study aimed to achieve the following objectives: Identify the concepts of TQM and organizational change and development, determine the extent of the application of Taif University for TQM in all its work and activities, Define the relationship between the application of TQM and organizational change and development at the university.

\section{Study Limitations}

Spatial boundaries: This study was limited to full-time academics at Taif University, Temporal boundaries: The application of this study during the second semester 2013, Objective limits: limited the study to go into the themes of TQM, organizational change and organizational development to full-time academics at Taif University.

\section{The Concept of TQM}

The concept of quality means different things depending on the nature of the business and industry, as well as the means of how performance characteristics of a particular product are especially when compared with the standards set in advance by the beneficiary or organization. Quality is to meet the expectations of the beneficiary or exceed them. Quality is defined as the suitability of the product to meet the intended use, or to meet the beneficiary expectations (Bank, John 2000).

As a result of the concepts emergence of education quality from different philosophical theories, difficulties have emerged in the creation of a uniform definition. The education quality is a series of communications with customers (students), with a view to providing them with knowledge, skills and attitudes that enable them to meet organizations expectations. The idea of quality concept in education has emerged from the integration in the organization overall, with the aim of finding the efficiency of the final product through an integrated system of work, efficiency and management development, and the need for the development of administrative capacity in terms of concept and application, and to enable the categories of work-related regulatory action in the atmosphere, to improve the performance and quality of the product (Massy, William 2003). TQM as the management of the organization is a whole, so as to be excellent in all aspects of products and services of interest to the beneficiary (Hazier 2001).

Oakland (2000) views TQM as a comprehensive approach to improve competitiveness, efficiency, flexibility through planning, organization, and understanding each activity. The involvement of everyone at all levels including the adoption of a strategic view for management quality. Focusing on preventing problems before they occur requires attention to remove existing barriers. TQM can be defined through the description of the basis adopted by the principle of "total dedication to the beneficiary". The description of the output to achieve beneficiaries loyalty to reach time and cost effectiveness. The continuous improvement through discussing various instruments and techniques to create climate of support and encouragement team work. TQM means a commitment to meet or exceed the needs of the 
beneficiary. The application of the principle adoption to search for quality in any place of work, starting to identify the needs of the beneficiary, and the end the assessment the beneficiary is satisfaction (Oakland, Johan 2000).

TQM in higher education as an integrated approach, it is applied in all levels of any educational organization to provide individuals with the opportunity to satisfy students and the beneficiaries learning needs. TQM in universities focuses on developing educational evaluation for improvement of the system. TQM will benefit the university as it lays the foundation of a new vision and philosophy to achieve the goals stated in the universities mission, which will boost employees morale and. This will change perceptions and attitudes towards the profession, which makes the learning environment a productive atmosphere (Hertz, 2002).

\section{Organizational Change}

Organizations of all types and forms are not fixed, but are in constant changes. Dealing with changes is so important for both beneficiaries and members of Organization. Changes in organization may affect the entire organization or substantial part due to various reasons such as; Organization diversification in goods and services, or organization culture including policies, strategies, procedures and working methods (Tenner A, 1992).

Husamann (2001) Defined the organizational change as a strategy for advanced education, aimed at changing beliefs, attitudes, values and organizational structures to match new requirements. To live with the challenges posed by High and rapid changes in the social environment, cultural, economic and other environment aspects (Arab Library, 2001).

\subsection{The Objectives of Change}

Change is an imperative need to deal with language and adapt to bring about the near and distant future. Proper planning is an important exercise for management practices in organization process, staffing, follow-up coordination, oversight and decision-making. It is linked to action plans and programs. Labor Department has a key role to identify objectives clarity and goals accuracy. One of the most important management issues to relate the overall quality management to the field management applications (Hussmann, 2001).

The organizational expression aims to reflect the desired change at both intellectual and automation levels. The need for internal and external communications between parties is needed to reach the organization goals. Organizational leadership has a key role to promote the establishment institutional vision (Heifetz R, 2002).

The starting point of change starts through the creation of full understanding of the implications for the forthcoming change to various institutions aspects, therefore the change plan effectiveness should be carried out through common framework set of questions that would help to reach an understanding and determine change content and its impact on the technical aspects for humanitarian organization (Godin S, 2001).

Organizational effectiveness understanding of quality management and comprehensive attention should be created through the exercise of various objectives and the administrative process at all levels linked to the organizational effectiveness to achieve goals related to human element and systems of the university's prevailing values. (Miliband D, 2004)

Organizational effectiveness is a concept of social construction, the control of non-substantive aspects are more important than substantive aspects to emphasize the flexible nature of the concept of organizational effectiveness for the measurement of organizational practice within the university due to the different images which show the organizational effectiveness and the multiplicity of indicators used by various parties linked to the University's work. (Schon D, 2000)

Enhancing organizational strategies practice in universities must be activated by organizational leadership through ideas exchange and establishment of a common experience rather than strict competition between the leaders of institutions. The transition from thought to thought should be activate within the framework of organizational ethics by communicating organizational goals to lay basis for continuing leadership, This is achieved through their success in influencing internal educational leaders to devote human and material resources in order to achieve its goals (Fullan D, 2004)

Many of the intellectuals basis their organizational success on "thinking of active organizational" which makes the duplication role of organizational leadership to include both identification of thought and vision. This act will help to achieve the goals of Vision devoted to increase revenue achievement of organizational goals. Organizational leadership is a key factor to achieve organizational coherence in terms of overall relations. Relationships can activate the organizational thinking to assume leadership and organizational process of internal balance to identify strategies and mechanisms to deal with changes of modernity. (Heifetz R, 2004) 


\section{Literature Review}

Previous studies dealing with the study in this section are a series of previous studies with the management of the comprehensive quality and change and organizational development: (Courtney, 1995) study, entitled TQM in higher education: academic staff perceptions of the President on the implementation of TQM in an institution of higher education. The objective of this study to collect and analyze data from higher education institutions that have applied TQM since April 1994 for a better understanding of the relationship between the entrance to the enterprise-wide application, in an interview on the scope of the Section, and the outputs of the TQM. The survey carried out by the work of sending mail to the heads of staff at (242) is an institution of higher education. And a researcher that (41\%) of the institutions (99) that responded. Have used TQM. Among these institutions (61\%) were applied using a comprehensive quality management of enterprise-wide portal. While (39\%) had used the entrance sections. It further found that the institutions that have applied TQM Enterprise-wide entrance is pointed to the significant benefits of the largest and less problems and achieved higher levels of success compared to the institutions that used the entrance sections.

Study (Irvin, 1995) aimed to the efforts to achieve TQM in the five research universities: the University of Cornell, University of Maryland (College Park), University of (Ann, Araborr) Michigan, Pennsylvania University of Pennsylvania and the University of Wisconsin Madison, the study raises the following question: Do you use research universities the main implementing TQM Strategies for achieving the different? In the view of the results of the study that TQM is a management initiative aimed to improve the quality of campus services and absorb the costs, and the number of teaching staff to learn and manage research on TQM, but the concern of the teaching staff in the use of TQM principles remain the exception more than the regulations established on campus for the five universities, the study suggests ways to solve (such as Quality Management District) to become the management of organizational change leading to the positive and widespread in the area of administrative services.

Study (Bass \& Dellana, 1996) aimed to change the use of TQM in the classroom management colleges. The study sample consisted of a member of the teaching faculties of the Department responded to them (318) of the study. The study found that (11\%) of respondents are applying the principles of TQM in the assessment of articles. While (61\%) of respondents have emphasized the teaching of the entrance to TQM. The study concluded that it is very difficult to measure the effectiveness of improvements in overall quality management of the members of the teaching staff at the practice.

Study (Yudof \& Busch, 1996) aimed to discuss the entrance of the comprehensive quality management with a focus on the elements that can be applied. The findings of this study indicated that the entrance to TQM provides technical research on the continuing improvement and strengthen the desire for change and the distribution of decision-making and the promotion of change towards a positive direction and shift the focus from external to the performance measures of internal performance measures.

Study (Xue, 1999) aimed to identify practices related to the overall quality of higher education institutions. This study focused on the quality of practices in the most and least successful implementation of quality in the academic environment. Was adopted by the researcher in the study on the construction of a model depends on the criteria proposed for the six core TQM developed by Malcolm Baldrj. The study consisted of two main phases. The first phase included the initial studies on the basis of this study was the study-building tool. The results of the study were analyzed based on criteria of quality Baldrj. The results of a researcher to study the distribution of institutions of higher education into three groups in terms of application of quality: quality in the application of the Junior with limited experience in the application of quality with long experience in the application of quality.

Study (Schaffer, 2000) entitled TQM requirements of the quality of undergraduate instruction, which emphasizes the challenges in higher education. The study was designed as the different procedures of qualitative research is a qualitative method used this study control group (test me - Exam dimensions) over the entire year focusing on building the academic quality of the analysis and information taken from interviews of faculty members and from the responses of students. The results indicated the absence of indications for the use of statistical quality in the classroom and focused information to this conclusion on the process itself. The study showed the use of the results of this study in an academic study of the other program to improve the quality and academic improvement.

Study (Dickerson, 2001) aimed to examining the concept of organizational change, as managers see the students, the study examined the specific directions of these managers to the organizational change, and the same degree of understanding of organizational change in their institutions. Also tried to study and, more broadly, to identify effective strategies in dealing with organizational change. The sample included employees in the affairs of the students who attended the Southern Union Conference on the university students in the city of Louisville, held in the period between 
6/11-8/11/1999. Study revealed the existence of significant and substantial differences among managers in the understanding of the planning and implementation of organizational change, and there were no significant differences and substantial connection with the process of assessing the understanding of organizational change. It also found significant and substantial differences between the upper and lower levels of managers in dealing with active planning and implementation of organizational change, and there were no significant differences and fundamental actor in dealing with the assessment of organizational change. These results indicated the existence of a gap between the upper and lower levels of the directors of Student Affairs. The results concluded that the development of organizational change based on organizational needs, and emphasized that the sample of the process of organizational change in the institutions necessary for the students. The managers at the three clear-cut policies and organizational change.

Study (Hertz, 2002) aimed to determine whether there is a relationship between the pattern of educational leadership and the possibility of the entrance to the application of TQM in higher education institutions, have limited the study to Alokadimipp departments at the University of Missouri-Rolla University Award-winning quality of the (1995). For the purpose of the application of the study prepared by the researcher to identify the leadership and the self-assessment of overall quality management in accordance with the standards Baldrige Award (Baldrige), resolution has been distributed to the heads of departments and staff to assess the head of each department. The results of the study showed that there is a strong relationship between the prevailing pattern of leadership in educational institutions and the possibility of application of TQM, and the transformation of a pattern leading to another directly connected with the possibility of application of TQM, and can benefit from access to quality standards at the university in question

Study (Lewis, 2003) aimed to determine the overall quality standards in higher education in Texas. The identification of the distribution of the sample consisted of (86) Director of Service and Head of the Department in universities in the state. The study found that there is a lack of standards in the application of TQM in higher education institutions are weak and follow-up surveillance and scrutiny. The findings also indicated that managers appreciate that universities apply quality standards with all the comprehensive requirements, while the heads of the sections opposite.

Most previous studies aimed to the following: knowledge of the link between the leadership styles of the heads of the institutions of higher learning and the performance of the overall behavior of the leadership quality, and the collection and analysis of data from higher education institutions that have applied TQM, and change the use of TQM in the classroom management colleges, and discuss the entrance of the comprehensive quality management with a focus on the elements that can be applied, the analysis of the concept of TQM, tools and methods and how to apply them in institutions of higher education.

It is clear from previous studies that focus on students do not have any contribution to the management and evaluation of previous studies were not intended to indicate the extent to which the application of quality standards in the comprehensive universities effectively. The present study, I believe that there is the possibility of adding some new and useful information that were not addressed in previous studies. It was important to address all sectors of the high educational sectors, namely, private universities in the Sultanate of Oman, the researcher hoped to propose some recommendations that may be helpful to decision-makers in these institutions in their endeavors to take advantage of the many advantages offered by the application of TQM in these institutions.

Researcher has benefited from previous studies of access to research and determine the study sample, the selection of search tools, and methods of statistical treatment, the most important results to compare the results of current research, which will help to clarify and interpret.

\section{Society and the Study Sample}

Be a community study of all full-time academics at Taif University (328) Admin, a random sample was selected by the Academy at the University, at (159) the Academy, and the distribution of a study (resolution) to them.

\section{Correct Instrument}

Was calculated as the role of TQM in practicing organizational change and development in Taif University through the following: the upper limit of the alternatives to a study (5) alternatives - the minimum for a study of alternatives (1)= $3-4$ levels (high, average, poor) $=1.33$ and, therefore, a minimum $1+1.33=2.33$, reducing the average $2.34+1.33=$ 3.67 , and maximum $=3.68$ and above, and thus become the weights of paragraphs: paragraph arithmetic average between (3.68 to 5.00) implies a high degree of exercise, and the paragraph on average between the computational (2.34 to 3.67) means the degree of exercise moderately, and the paragraph between the arithmetic average (1.00 to 2.33) means the degree of exercise is low. 


\subsection{Study Instrument}

Formed a study in the final image of the following: Section I: These are general statements (independent variables of the study) on the transponder and include the variables: age, gender, qualifications, and years of experience, the nature of work, academic programs, the workplace, and the work site. Section II: In the paragraphs of the resolution by the application of TQM and its relationship with organizational change and development in the Al al-Bayt University from the point of view of the Academy. consists of (42), paragraph distributed for each of the seven areas, which is as follows: Focus on students, Organizational culture, The design of operations, Support senior management of quality, Continuous improvement, Focus on academics, Quality assurance the area of religious harmony, and the psychological and the social consensus, and the area of moral consensus, the instrument has been built along the lines of a measure of the five-Eckert, and as follows: No use, Slightly, Sometimes, Often, Always, and the digital signs on the following ranking: $(5,4,3,2,1)$.

\subsection{Veracity the Instrument to the Test}

Make sure the truth was apparent through the identification of the presentation to the committee of arbitrators, who are university professors and experts for an opinion on the extent of the measurement of each question to be measured by, the extent and clarity of questions, and the safety of language, in the light of suggestions and amendments both deletion, addition or amendment, introduced by the researcher, has emerged as the initial resolution in the attachment, and the final, and considered consent ( $80 \%$ ) of the arbitrators on the vehicle evidence of the apparent sincerity, and this is what the Gold (Bloom) where he was the proportion of agreement (70\%) and more evidence of the apparent sincerity.

The stability of intention has been to ensure consistency through the test and retest (Test-Retest), on a sample of (35) and the subjects dealt with outside the study sample, four weeks between the first application and second application, retrieved by using a factor of stability Pearson correlation coefficient (Pearson Correlation Coefficient) of the device and found that (0.85), which refers to the stability of transactions rely on the Instrument for the purposes of the study as in Table 1.

Table 1

\begin{tabular}{|c|c|c|}
\hline No & Areas & The area factor of the Agreement \\
\hline 1. & Focus on students & 0.88 \\
\hline 2. & Organizational culture & 0.79 \\
\hline 3. & The design of operations & 0.86 \\
\hline 4. & Support senior management of quality & 0.90 \\
\hline 5. & Continuous improvement & 0.92 \\
\hline 6. & Focus on academics & 0.83 \\
\hline \multirow[t]{2}{*}{7.} & Quality assurance & 0.77 \\
\hline & Whole instrument & 0.85 \\
\hline
\end{tabular}

10.3 The Study Design and Statistical Treatment

This study used descriptive analytical approach due to the nature of the collected data. Using (SPSS) and Two Way ANOVA.

\subsection{The Variables of the Study}

This study included the following variables: Age, and has four levels: (Less than 30 years, 30 - less than 40, 40 - less than 50, 50 years and more), Gender, and has two levels: (male and female), Degree, and has two levels: (Doctor and Master). Level of scientific and has five levels: (Professor, Associate Professor, Assistant Professor, Lecturer, and Assistant Teacher). Experience, and has three levels: (10 years and over, Less than 10 years, Less than 5 years). The nature of work, and has two levels: (Academic, Academic work of the administrative). Programs and has five levels: (Engineering, Social Service, Education, and Economic and administrative Sciences, Technology and Applied Science). And Dependent variable: the sample estimates of the Role of TQM in Practicing Organizational Change and Development.

\section{The Results of the Study}

1). What is the role of TQM in organizational change and development in Taif University on students, Organizational culture, design of operations, support senior management for quality, Continuous improvement, academics and Quality assurance? 
Table 2 describes the role of TQM in practicing organizational change and development in Taif University on students. The calculation was based on averages and standard deviations.

Table 2

\begin{tabular}{|c|c|c|c|c|}
\hline $\mathbf{T}$ & Focus on students & $\begin{array}{l}\text { The } \\
\text { rank }\end{array}$ & Mean & $\begin{array}{c}\text { Std. } \\
\text { Deviation }\end{array}$ \\
\hline 1. & $\begin{array}{l}\text { University offers educational services to meet the actual } \\
\text { needs of students. }\end{array}$ & 1 & 4.37 & 0.97 \\
\hline 2. & $\begin{array}{l}\text { Curriculum is being designed in light of the needs of labor } \\
\text { markets. }\end{array}$ & 3 & 4.27 & 0.73 \\
\hline 3. (Note 1$)$ & $\begin{array}{l}\text { Develop special programs to follow up the university } \\
\text { graduates. }\end{array}$ & 2 & 4.30 & 0.80 \\
\hline 4. & $\begin{array}{l}\text { University analyzed data on the labor market to provide } \\
\text { appropriate educational services. }\end{array}$ & 4 & 4.14 & 1.01 \\
\hline 5. & $\begin{array}{l}\text { Dealing with complaints from university students, first to } \\
\text { avoid the first to occur in the future }\end{array}$ & 5 & 4.09 & 1.03 \\
\hline \multirow[t]{2}{*}{6.} & $\begin{array}{l}\text { University provides a sufficient level of support services } \\
\text { to the educational process. }\end{array}$ & 6 & 4.06 & 1.06 \\
\hline & Whole area & $2 *$ & 4.21 & 0.66 \\
\hline
\end{tabular}

The arithmetic averages and standard deviations where indicating a high degree of significance throughout the answers of the addressed questions.

The second area: Organizational culture, include this dimension of (5) by paragraph, each paragraph describes the role of TQM in practicing organizational change and development in Taif University, in terms of Organizational culture, for this calculation was calculated averages and standard deviations and the level of each paragraph of the paragraphs and the whole area is also on the agenda No. (3).

Table 3

\begin{tabular}{clccc}
\hline T & \multicolumn{1}{c}{ Organizational culture } & $\begin{array}{c}\text { The } \\
\text { rank }\end{array}$ & Mean & $\begin{array}{c}\text { Std. } \\
\text { Deviation }\end{array}$ \\
\hline 7. & $\begin{array}{l}\text { The university fosters a culture that is consistent with the } \\
\text { appropriate orientation of TQM. }\end{array}$ & 4 & 3.85 & 0.99 \\
8. $\begin{array}{l}\text { Characterized by the University to other universities, a } \\
\text { culture in which employees believe in the quality of each } \\
\text { activity. }\end{array}$ & 3 & 3.87 & 1.11 \\
9. $\begin{array}{l}\text { The university organize courses to educate workers in the } \\
\text { basics of quality }\end{array}$ & 1 & 4.18 & 0.84 \\
10. $\quad \begin{array}{l}\text { University organizes seminars conferences to establish a } \\
\text { culture of quality. }\end{array}$ & 5 & 3.39 & 1.20 \\
The dominant culture in the university is that quality is \\
$\begin{array}{l}\text { everyone's responsibility. } \\
\quad \text { Whole area }\end{array}$ & 2 & 4.10 & 1.24 \\
\hline
\end{tabular}

Table 3 arithmetic averages and standard deviations, grade each paragraph of the Organizational culture and the whole area, as they to win paragraph (9) / "The university organize courses to educate workers in the basics of quality" their average ranked first (4.18), and the paragraph (11) / "The dominant culture in the university is that quality is everyone's responsibility" in the second arithmetic average (4.10), and the paragraph (8) / "Characterized by the University to other universities, a culture in which employees believe in the quality of each activity" in the third place my average (3.87). This means that the role of TQM in practicing organizational change and development in Taif University, in terms of Organizational culture (high), where the average responses (3.88).

The third area: The design of operations, include this dimension of (4) by paragraph, each paragraph describes the role of TQM in practicing organizational change and development in Taif University, in terms of The design of operations, for this calculation was calculated averages and standard deviations and the level of each paragraph of the paragraphs and the whole area is also on the agenda No. (4). 
Table 4

\begin{tabular}{|c|c|c|c|c|}
\hline $\mathbf{T}$ & The design of operations & $\begin{array}{l}\text { The } \\
\text { rank }\end{array}$ & Mean & $\begin{array}{c}\text { Std. } \\
\text { Deviation }\end{array}$ \\
\hline 12. & $\begin{array}{l}\text { University has an interest to achieve } \\
\text { coordination among different departments }\end{array}$ & 2 & 3.49 & 1.38 \\
\hline 13. & $\begin{array}{l}\text { League rules are applied to achieve effective } \\
\text { performance. }\end{array}$ & 4 & 3.11 & 1.53 \\
\hline 14. & $\begin{array}{l}\text { Allocate adequate resources for university research } \\
\text { and development. }\end{array}$ & 3 & 3.43 & 1.40 \\
\hline & The University can use its resources efficiently. & 1 & 3.62 & 1.52 \\
\hline & Whole area & $7 *$ & 3.41 & 1.33 \\
\hline
\end{tabular}

Table 4 arithmetic averages and standard deviations, grade each paragraph of the design of operations and the whole area, as they to win paragraph (15) / "The University can use its resources efficiently" their average ranked first (3.62), and the paragraph (12) / "University has an interest to achieve Coordination among different departments" in the second arithmetic average (3.49), and the paragraph (14) / "Allocate adequate resources for university research and development" in the third place their average (3.43). This means that the role of TQM in practicing organizational change and development in Taif University, in terms of the design of operations (high), where the average responses (3.41).

The fourth area: Support senior management of quality, include this dimension of (6) by paragraph, each paragraph describes the role of TQM in practicing organizational change and development in Taif University, in terms of Support senior management of quality, for this calculation was calculated averages and standard deviations and the level of each paragraph of the paragraphs and the whole area is also on the agenda No. (5)

Table 5

\begin{tabular}{clccc}
\hline $\mathbf{T}$ & \multicolumn{1}{c}{ Support senior management of quality } & $\begin{array}{c}\text { The } \\
\text { rank }\end{array}$ & Mean & $\begin{array}{c}\text { Std. } \\
\text { Deviation }\end{array}$ \\
\hline 16. & 3 & 4.32 & 1.00 \\
& $\begin{array}{l}\text { Support the senior management staff of the } \\
\text { University's efforts towards the implementation of } \\
\text { comprehensive quality management system. }\end{array}$ & 6 & 3.98 & 1.23 \\
17. $\begin{array}{l}\text { Keep pace with the senior management of the } \\
\text { University of change management processes are } \\
\text { successful. }\end{array}$ & 5 & 4.00 & 1.08 \\
18. $\quad \begin{array}{l}\text { Provide senior management of the physical facilities } \\
\text { for the University of application of TQM system. } \\
\text { Respect the senior management of the University of } \\
\text { distinguished accomplishments. }\end{array}$ & 2 & 4.33 & 1.09 \\
20. $\quad \begin{array}{l}\text { Adopt the updated strategic plan the university went } \\
\text { clear about the overall quality management } \\
\text { applications. }\end{array}$ & 4 & 4.16 & 1.16 \\
21. & $\begin{array}{l}\text { Administration to involve subordinates in } \\
\text { decision-making on employment issues. }\end{array}$ & 1 & 4.37 & 1.02 \\
\hline & Whole area & $3 *$ & 4.19 & 0.81 \\
\hline
\end{tabular}

Table 5 arithmetic averages and standard deviations, grade each paragraph of the Support senior management of quality and the whole area, as they to win paragraph (21)/ "Administration to involve subordinates in decision-making on employment issues" their average ranked first (4.37), and the paragraph (19)/ "Respect the senior management of the University of distinguished accomplishments" in the second arithmetic average (4.33), and the paragraph (16)/ "Support the senior management staff of the University's efforts towards the implementation of comprehensive quality management system" in the third place my average (4.32).

This means that the role of TQM in practicing organizational change and development in Taif University, in terms of Support senior management of quality (high), where the average responses (4.19).

The fifth area: Continuous improvement, include this dimension of (6) by paragraph, each paragraph describes the role of TQM in practicing organizational change and development in Taif University, in terms of Continuous improvement, 
for this calculation was calculated averages and standard deviations and the level of each paragraph of the paragraphs and the whole area is also on the agenda No. (6).

Table 6

\begin{tabular}{clccc}
\hline T & \multicolumn{1}{c}{ Continuous improvement } & $\begin{array}{c}\text { The } \\
\text { rank }\end{array}$ & Mean & $\begin{array}{c}\text { Std. } \\
\text { Deviation }\end{array}$ \\
\hline 22. & $\begin{array}{l}\text { The university is working to modernize their } \\
\text { curricula. }\end{array}$ & 1 & 4.25 & 1.12 \\
23. $\quad \begin{array}{l}\text { The university is working on updating the criteria for } \\
\text { accepting new students. }\end{array}$ & 3 & 4.13 & 1.02 \\
24. $\quad \begin{array}{l}\text { The university adopts a method of continuous } \\
\text { improvement work. }\end{array}$ & 4 & 4.01 & 1.03 \\
25. $\quad \begin{array}{l}\text { The University develops the levels of } \\
\text { scientific research }\end{array}$ & 2 & 4.23 & 1.05 \\
26. $\begin{array}{l}\text { Be conducted to develop sufficiently to improve the } \\
\text { efficiency of libraries in the areas of education. } \\
\text { The administration encourages all }\end{array}$ & 5 & 4.00 & 1.31 \\
$\quad \begin{array}{l}\text { academics to the continuous development } \\
\quad \text { Whole area }\end{array}$ & $6 * 3.96$ & 1.24 \\
\hline
\end{tabular}

Table 6 Arithmetic averages and standard deviations, grade each paragraph of the Continuous improvement and the whole area, as they to win paragraph (22) / "The university is working to modernize their curricula" their average ranked first (4.25), and the paragraph (25)/"The University develops the levels of scientific research" in the second arithmetic average (4.23), and the paragraph (23) / "The university is working on updating the criteria for accepting new students" in the third place my average (4.13). This means that the role of TQM in practicing organizational change and development in Taif University, in terms of Continuous improvement (high), where the average responses (4.10).

The sixth area: Focus on academics, include this dimension of (7) by paragraph, each paragraph describes the role of TQM in practicing organizational change and development in Taif University, in terms of Focus on academics, for this calculation was calculated averages and standard deviations and the level of each paragraph of the paragraphs and the whole area is also on the agenda No. (7).

Table 7

\begin{tabular}{clccc}
\hline T & \multicolumn{1}{c}{ Focus on academics } & $\begin{array}{c}\text { The } \\
\text { rank }\end{array}$ & Mean & $\begin{array}{c}\text { Std. } \\
\text { Deviation }\end{array}$ \\
\hline 28. & $\begin{array}{l}\text { The university encourages to academic performance. } \\
\text { 29. }\end{array} \quad \begin{array}{l}\text { Use the university system for the integration of } \\
\text { academics active in the new work. }\end{array}$ & 6 & 4.28 & 1.01 \\
30. & $\begin{array}{l}\text { Academic performance is assessed in the light of } \\
\text { quality standards. }\end{array}$ & 3 & 4.26 & 1.07 \\
31. & $\begin{array}{l}\text { The university succeeds in maintaining the high } \\
\text { spirits of the academics. }\end{array}$ & 5 & 4.20 & 0.87 \\
32. & $\begin{array}{l}\text { Not delayed in the payment of university finance. } \\
\text { 33. }\end{array}$ & 2 & 4.27 & 0.90 \\
$\quad \begin{array}{l}\text { The Department of the University to the team spirit at } \\
\text { 34. }\end{array}$ & 4 & 4.24 & 0.93 \\
\hline & Performance measures and clears to all academics. & 7 & 4.13 & 0.98 \\
\hline
\end{tabular}

Table 7 arithmetic averages and standard deviations, grade each paragraph of the Focus on students and the whole area, as they to win paragraph (28) / "The university encourages to academic performance" their average ranked first (4.28), and the paragraph (32)/"Not delayed in the payment of university finance" in the second arithmetic average (4.27), and the paragraph (30)/ "Academic performance is assessed in the light of quality standards" in the third place my average (4.26). This means that the role of TQM in practicing organizational change and development in Taif University, in terms of Focus on students (high), where the average responses (4.22).

The seventh area: Quality assurance, include this dimension of (8) by paragraph, each paragraph describes the role of TQM in practicing organizational change and development in Taif University, in terms of Quality assurance, for this 
calculation was calculated averages and standard deviations and the level of each paragraph of the paragraphs and the whole area is also on the agenda No. (8).

Table 8

\begin{tabular}{|c|c|c|c|c|}
\hline $\mathbf{T}$ & Quality assurance & $\begin{array}{l}\text { The } \\
\text { rank }\end{array}$ & Mean & $\begin{array}{c}\text { Std. } \\
\text { Deviation }\end{array}$ \\
\hline 35 & $\begin{array}{l}\text { Philosophy of the University has focused on the } \\
\text { performance of any work properly the first time. }\end{array}$ & 2 & 4.13 & 1.04 \\
\hline 36. & $\begin{array}{l}\text { University adopts a prevention of errors rather than } \\
\text { correcting after they occur. }\end{array}$ & 1 & 4.20 & 0.97 \\
\hline 37. & $\begin{array}{l}\text { Achievement levels are checked to ensure } \\
\text { compliance with quality standards of performance } \\
\text { assessments. }\end{array}$ & 7 & 3.92 & 1.28 \\
\hline 38. & $\begin{array}{l}\text { University establishes specific requirements or the } \\
\text { performance of each activity. }\end{array}$ & 5 & 3.96 & 1.30 \\
\hline 39. & $\begin{array}{l}\text { Students interested in study and attach serious } \\
\text { enough. }\end{array}$ & 3 & 4.10 & 1.11 \\
\hline 40. & Curricula reflect the needs of the labor market. & 6 & 3.93 & 1.26 \\
\hline 41. & $\begin{array}{l}\text { Succeed in attracting the university teaching staff } \\
\text { members of the privileged. }\end{array}$ & 4 & 4.07 & 0.97 \\
\hline \multirow[t]{2}{*}{42.} & $\begin{array}{l}\text { Successful university in the preparation of } \\
\text { appropriate cadres of graduates, and philosophy of } \\
\text { the University has focused on the performance of } \\
\text { any work properly the first time. }\end{array}$ & 8 & 3.50 & 1.30 \\
\hline & Whole area & $5 *$ & 3.98 & 0.84 \\
\hline
\end{tabular}

Table 8 arithmetic averages and standard deviations, grade each paragraph of the Quality assurance and the whole area, as they to win paragraph (36) / "University adopts a prevention of errors rather than correcting after they occur" their average ranked first (4.20), and the paragraph (35) /"Philosophy of the University has focused on the performance of any work properly the first time" in the second arithmetic average (4.13), and the paragraph (39)/ "Students interested in study and attach serious enough" in the third place my average (4.10). This means that the role of TQM in practicing organizational change and development in Taif University, in terms of Quality assurance (high), where the average responses (3.93).

Discuss the results of the first question: first main of the question provides as follows: the trends of the academic at Taif University about the reality of the applications of TQM (elements of the seven adopted in this study). Clear answer to the question of the President and the study questions in the sub-branching, as shown in table of the academic trends towards TQM applications in the university have been positive in the six elements of a comprehensive quality management (continuous improvement, organizational culture, the societal dimension of the University, to support the senior management of the quality, focus on academics, quality assurance), while some trends of the academic applications of TQM elements in the university (students and focus on the design of operations) neutral, and the organizational culture with regard to university courses and organize conferences and workshops to establish a culture of quality.

The University to foster a culture consistent with the appropriate orientation of TQM, as well as the dominant culture is that the university's quality is everyone's responsibility, With regard to the focus on academics, the university does not delay the payment of financial dues to them, and encouraging them to performance, as well as the team spirit in the work, as well as being evaluated in the light of academic quality standards. This confirms the result of the presence of a positive correlation relationship therefore, rejects the hypothesis of zero, and accepts the alternative hypothesis. This finding corresponds with the Irvin (1995), Dickerson (2001), and Hertz, (2002), and Bass \& Dellana (1996).

It may be the reason for the positive in that modern education is aimed at education investment through the development of human life and the employment of his energies in order to serve the community to come to that, we need to manage effective, targeted and sophisticated; because the essence of management is how to deal with the human and material resources to achieve its goals with little effort The human cost of the lowest in the shortest time possible. In view of current developments and future challenges in all spheres of political, social, cultural, technological and informatics. We must focus on quality (Quality) any quality commensurate with the needs of the individual and society. This confirms the result of the presence of a positive correlation relationship therefore, rejects 
the hypothesis of zero, and accepts the alternative hypothesis. This finding corresponds with the Irvin (1995), Dickerson (2001), and Hirtz, (2002), Huang (1994), and Courtney (1995).

With regard to ensuring quality work to encourage University students to pay attention to study, as well as the philosophy of the University has focused on the performance of any work properly the first time; adopt the principle of the University of Prevention of errors rather than correcting errors after they occur. The items shown neutral who by academics about the applications of TQM and the design of the first operations, the views of respondents, was that the university does not allocate adequate resources for research and development, and apply an effective management system to achieve outstanding performance, and also do not develop appropriate performance measures for each function of the university.

And the second concentrating on the students at the university, where the views of respondents that there are weaknesses in the programs developed by the University to follow up on graduates, and to design programs of study at the university is Highly consistent with the requirements demanded by the labor market, and analyze the data for the University of labor market to provide educational services appropriate. This confirms the result of the presence of a positive correlation relationship therefore, rejects the hypothesis of zero, and accepts the alternative hypothesis. This finding corresponds with the Irvin (1995), Dickerson (2001), and Hertz, (2002), Schaffer (2000), Lewis (2003).

Can increase the effectiveness of performance in Taif University through the achievement of its objectives and principles and take into account some important foundations for such as administration, democracy and collective leadership, human relations, and development of information management system and adopt a philosophy of total quality in the inputs, processes and outputs of the university. This confirms the result of the presence of a positive correlation relationship therefore, rejects the hypothesis of zero, and accepts the alternative hypothesis. This finding corresponds with the Irvin (1995), Dickerson (2001), and Hertz, (2002), Yudof \& Busch (1996), and Xue (1999).

It may be the reason for the positive in that TQM means to contribute effectively to the administrative and organizational system of all elements of efficiency in the investment of available resources of raw material, equipment and human resources, information, management, strategy, standards and specifications, so that all contribute in the quest to achieve the goal of the university, which is focused to achieve the greatest and the values of loyalty and belonging, motivation, achievement and self-realization, and review of the educational non-direct product, and It may be the reason that TQM is the system that can achieve improvement in the institutions that are inclusive of everything, continuity and other principles of preparing for the comprehensive quality.

The achievement of total quality in the school does not come only through knowledge of the wishes and needs of beneficiaries and the work in an effective manner to help achieve and the context of the two types of mass participation in the planning and application support for improvement in the quality assurance framework. This confirms the result of the presence of a positive correlation relationship therefore, rejects the hypothesis of zero, and accepts the alternative hypothesis. This finding corresponds with the Irvin (1995), Dickerson (2001), and Hirtz, (2002), Huang (1994), Courtney (1995), and Bass \& Dellana (1996).

2). Are there any statistical significant differences at the level $(\alpha \geq 0,05)$ due to the Age, gender, Degree, Level of scientific, experience, nature of work and Programs?

And to identify whether there is a difference between the average responses of the study in the area of consensus about the whole instrument, analysis of variance was used bilaterally, and table no. (9) Makes clear.

Table 9. Tests of between subjects effects dependent on whole instrument

\begin{tabular}{lccccc}
\hline \multicolumn{1}{c}{ Source } & $\begin{array}{c}\text { Sum of } \\
\text { Squares }\end{array}$ & df & $\begin{array}{c}\text { Mean } \\
\text { Square }\end{array}$ & F & Sig \\
\hline AGE & 0.743 & 3 & 0.248 & 0.642 & 0.589 \\
GENDER & 0.438 & 1 & 0.438 & 1.135 & 0.288 \\
DEGREE & 0.991 & 2 & 0.496 & 1.285 & 0.280 \\
LEVEL & 0.483 & 2 & 0.241 & 0.626 & 0.536 \\
EXPERIE & 0.104 & 1 & 0.104 & 0.271 & 0.604 \\
NATURE & 0.420 & 1 & 0.420 & 1.089 & 0.298 \\
PROGRAMS & 0.980 & 4 & 0.245 & 0.635 & 0.638 \\
Error & 55.553 & 144 & 0.386 & & \\
\hline Corrected Total & 60.534 & 158 & & & \\
\hline
\end{tabular}

Reveals the Table 9 that there is no statistically significant difference in the role of TQM in practicing organizational change and development in Taif University due to the variables: the Age, gender, Degree, Level of scientific, 
experience, nature of work and Programs; there is no need to test the application of the Scheffe a posteriori comparisons to determine which is the most appreciated of the variable level.

Discuss the results of the second question: This means that the role of TQM in practicing organizational change and development in Taif University, where all workers are equal without regard to the Age, gender, Degree, Level of scientific, experience, nature of work and Programs. Can be explained by the fact that the study sample of workers in Taif University were able to appreciate the role of TQM in practicing organizational change and development in Taif University, without regard to gender or type of work they are doing, which proves that that their estimates were the same pace in the application, and in the knowledge that confirms that the transfer of a participating or learning or training, there may be another reason may be circumstances in which the study took a sample of workers in Taif University are similar in the knowledge and application, where the expertise acquired skills rates close. It may be the reason for the study similar to a sample of workers in Taif University in terms of average age, and their environments, and their social, cultural and economic level, as well as they Mutation capabilities and qualifications and service.

Add The TQM and its impact on the development of the performance of the University and the student. Through this the researcher has contributed to bridging the gap plaguing the Arab library, in particular with regard to studies of TQM and its impact on the development of academic performance. It may be the cause of improving the preparation of the student and to provide enjoyable educational experiences of working on the development of his personality in an integrated manner, and the Education Department to adopt a new philosophy is to challenge students to learn to take responsibility and initiative, and development through research and innovation, the adoption of the philosophy of good development requires modernization of management, and continuous improvement of production and services through management guidance, and the formation of task forces, and the continuity of the development process, and further on-the-job training by qualified instructors for self-development of each individual.

\section{Recommendations}

The results of this study lead to a number of recommendations and the scientific process, as follows:

1). Discuss the concept of total quality in education and the identification of the different visions of intellectual addressed, and to determine the overall quality standards in education, and knowledge of the overall quality models that can be applied in educational institutions, and to identify how to control the quality of education, and identify areas for the application of TQM in educational institutions.

2). Attempt to survey and describe the most comprehensive quality management standards were already in place in educational institutions in Saudi, and actors in creating standards of TQM and its role in the development of performance in kingdom of Saudi Arabian universities, and derivation of criteria based on TQM in order to enhance the educational performance.

3). The evolution of TQM educational management organization is a systematic way to bring about the desired change in the university, which emphasizes principles, methods, instruments and procedures to provide data on all aspects of its work and then interpreted and analyzed in order to take appropriate decisions to develop and improve academic performance.

4). The need to promote sufficient support to educational process and organizes seminars conferences to establish a quality culture, to enforce rules to achieve effective performance, to Keep pace with the senior management of the University to change management processes to be successful, and to encourage continuous administrative development for all academics.

5). The creation or provision of Performance measures and clears to all academics, and Successful University in the preparation of appropriate cadres of graduates, and philosophy of the University has focused on the performance of any work properly the first time.

\section{References}

Bank, John. (2000). The essence of Total Quality Management. Prentice Hall.

Bass, Kenneth, \& Dellana, Scott. (1996). Assessing the use of Total Quality Management in the business school $\begin{array}{lllll}\text { classroom. Journal of education for } & \text { business, } & 71(6), & 123 .\end{array}$ http://dx.doi.org/10.1080/08832323.1996.10116809

Courtney, John Eric. (1995). Total Quality Management in Higher Education: Perceptions of the Chief Academic Officer of the Results of Implementing TQM in Their Higher Education institution. DAI-A57/03, P.939. 
Dewhurst, F., Martinez-Lorente, A., \& Dale, B. (1999). TQM in public organizations: an examination of the issues. Managing Service Quality. Managing Service Quality, 9(4), 265-273. http://dx.doi.org/10.1108/09604529910273210

Escrig-Tena, A. B. (2004). TQM as a competitive factor: A theoretical and Empirical Analysis. International Journal of Quality \& Reliability Management, 21(6), 612-637. http://dx.doi.org/10.1108/02656710410542034

Fullan, M. (2004). Whole System Reform. Paper Presented for New American Schools, Arlington, VA.

Fullan, M. (2005). Leadership and Sustainability. Thousand Oaks, Corwin Press.

Godin, S. (2001). Unleashing the Idea Virus. New York, Do You, Zoon.

Hazier, Jay, \& Render, Barry. (2001). Operations Management. Prentice-Hall.

Heifetz, R. (2004). The Adaptive Challenge. Boston: Harvard Business School Press.

Heifetz, R., \& Linsky, M. (2002). Leadership on the Lien: Staying Alive through the Dangers of Leading. Boston: Harvard Business School.

Hertz, P. (2002). Effective leadership for total Quality Management. (Doctoral Dissertation, University of Missouri Rolla, AAT 3053626.

Hertz, Zhiming. (2002). Effective Practices of Continuous Quality Improvement in United States Colleges and Universities. DAI-A59/07.

Husamann, D, \& Miller, M. (2001). Improving Distance Education Presentations of program Administration. Online Journal of Distance learning Administration, 12(4), 132.

Irvin, Andrew H. (1995). Leadership Strategies for the Implementation of Total quality Management at five Research Universities. Unpublished Doctoral Dissertation. Michigan State University, U.S.A.

Lewis, Smith. (2007). Total Quality in Higher Education. Educational Management, 36(14), 237.

Massy, William. (2003). Honoring the trust: Quality and cost containment in Higher Education. New York: Anker publishing.

Miliband, D. (2004). Personalized Learning. Building New Relationships with Schools. London, Rout ledge, Flamer.

Oakland, John. (2000). Total Quality Management. Butterworth Heinemann.

Schaffer, James Bernard. (2001). Total Quality Management an Academic Cultural Initiative In Higher Education. Dissertation Abstract. DAI-A61/04, p1321.

Schon, D. (2000). The Reflective Practitioner. London: Rutledge Flamer.

Taylor-Powell E., \& Richardson B. (1990). Issues programming changes Extension. Journal of Extension, 28(summer), 16-17.

Tenner A., \& DeToro, J. (1992). Total quality management. Reading. MA: Addison-Wesley.

The Arab Society for Certified Accountants, Management strategies for operations, the Arab community of professional accountants. (2001). Operations management and strategy. The Arab library, Oman.

Xue, Zhiming. (1999). Effective Practices of Continuous Quality Improvement in United States Colleges and Universities. DAI-A59/07, P.22941.

Yudof, M., \& Busch, Vishniac. (1996). Total Quality Myth or Management in universities. Change: The Magazine of Higher Learning, 28(6), 117. http://dx.doi.org/10.1080/00091383.1996.9937148

Note

Note 1. All above information where obtained from students records to measure the impact of TQM application effect. 